\title{
PERTUMBUHAN PENDAPATAN ASLI DAERAH DAN KONTRIBUSINYA TERHADAP BELANJA DAERAH KOTA MANADO
}

\author{
Wendy Rawung \\ Theodora M. Katiandagho \\ Melissa Lady G. Tarore
}

\begin{abstract}
This study aims to find out how much the growth of Regional Original Income (PAD) and the Contribution of PAD to the Regional Expenditures of the City of Manado. This research was conducted for three months from September to November 2017. The data used in this study were secondary data collected from the Central Statistics Agency (BPS) of North Sulawesi. The results showed that the growth of PAD from 2011-2016 was fluctuating with the highest growth rate in 2012 of 24.49\% and the lowest in 2015 of $4.22 \%$ and with an average of $15.33 \%$. The contribution of Regional Original Revenue to Regional Expenditures for 2011-2016 is still in the lack of criteria, with the highest contribution in 2014 amounting to $19.08 \%$ and the lowest in 2016 amounting to $14.91 \%$ and the average contribution to Regional Expenditure of $15.75 \%$. This means that the Manado City government needs to improve performance more in exploring new sources of Regional Revenue and maximizing existing PADs to increase Regional Original Income Contributions to Manado City Regional Expenditures. *eprm*.
\end{abstract}

Keywords: growth, contribution, PAD, Regional Expenditures, City of Manado.

\begin{abstract}
ABSTRAK
Penelitian ini bertujuan untuk ingin mengetahui seberapa besar pertumbuhan Pendapatan Asli Daerah (PAD) dan Kontribusi PAD terhadap Belanja Daerah Kota Manado. Penelitian ini dilakukan selama tiga bulan dari bulan September sampai dengan bulan November 2017. Data yang digunakan dalam penelitian ini adalah data sekunder yang dikumpulkan dari Badan Pusat Statistika (BPS) dan diolah. Hasil penelitian menunjukkan bahwa pertumbuhan PAD dari tahun 2011-2016 cenderug fluktuatif dengan angka pertumbuhan tertinggi di tahun 2012 sebesar 24,49\% dan terendah pada tahun 2015 sebesar 4,22\% dan dengan rata-rata15,33\%. Kontribusi Pendapatan Asli Daerah terhadap Belanja Daerah 20112016 masih dalam kriteria yang kurang, dengan kontribusi tertinggi pada tahun 2014 sebesar 19,08\% dan terendah pada tahun 2016 sebesar 14,91\% dan rata-rata kontribusinya terhadap Belanja Daerah sebesar $15,75 \%$. Artinya, pemerintah Kota Manado perlu lebih meningkatkan kinerja dalam menggali lagi sumber-sumber Pendapatan Asli Daerah yang baru dan memaksimalkan PAD yang sudah ada, untuk meningkatkan Kontribusi Pendapatan Asli Daerah terhadap Belanja Daerah Kota Manado. *eprm*.
\end{abstract}

Kata kunci: pertumbuhan, kontribusi, PAD, Belanja Daerah, Kota Manado.

\section{PENDAHULUAN}

\section{Latar Belakang}

Pada tahun 2004 pemerintah pusat mengeluarkan Undang-undang. No 34 mengenai adanya kewenangan daerah dan sebagai implikasinya adanya desentralisasi fiskal. Kebijakan ini merupakan tantangan bagi pemerintah daerah untuk mengelola sumber daya yang ada di daerahnya secara lebih efisien. Daerah-daerah yang memiliki potensi sumber daya masing-masing mendapat kebebasan untuk meningkatkan kreatifitas dalam mengelola dan mengembangkan potensi sumber daya daerahnya (Firstanto, 2015).

Dengan pelaksanaan ini membuat setiap daerah harus mandiri dalam melaksanakan kewenangannya masing-masing, pemerintah daerah dalam mengatur seluruh urusan pemerintahan dan memungkinkan daerah yang bersangkutan mengatur dan mengurus kepentingan masyarakat setempat. 
Kewenagan otonomi yang luas mewajibkan pemerintah daerah untuk meningkatkan pelayanan dan kesejahteraan masyarakat secara demokratis, adil merata, dan berkesinambungan (Halim, 2007). Dengan kebijakan otonomi daerah diharapkan seluruh daerah di Indonesia tidak hanya bergantung terhadap pemerintah pusat tetapi juga mampu melaksanakan semua urusan pemerintahan dan pembangunan dengan bertumpu pada Pendapatan Asli Daerah (PAD) yang dimilikinya.

PAD merupakan suatu penerimaan yang berasal dari sumber ekonomi dari daerah tersebut, menurut Undang-undang no. 23 tahun 2014 pasal 285 tentang pemerintahan daerah disebut Sumber pendapatan daerah terdiri dari 3 sumber yang (1) pendapatan asli daerah yaitu Pajak, Retribusi, Hasil pengelolaan kekayaan daerah yang dipisahkan dan lain-lain pendapatan daerah yang sah. (2) Pendapatan transfer dan (3) Lain-lain pendapatan daerah yang sah. Pendapatan terpenting dari retribusi dan pajak daerah adalah pemasukan terbesar kabupaten dan kota. Terutama untuk daerah yang memiliki sumber daya alam yang terbatas, Penerimaan dari pajak danretribusi daerah yang tinggi bisa menggambarkan baiknya pertumbuhan PAD dari tahun ke tahun. Peningkatan PAD sebagai sumber pembiayaan dalam penyelenggaraan otonomi daerah akan menentukan keberhasilan kinerja pembangunan di daerah pada masa yang akan datang (Nugroho, 2012).

Menurut Soleha (2012), pelaksanaan pembangunan daerah diarahkan untuk mewujudkan pemerataan pembangunan dalam rangka untuk meningkatkan pendayagunaan potensi-potensi yang dimiliki secara optimal. Dalam melaksanakan berbagai kegiatan yang berkaitan dengan pelaksanaan daerah tentu memerlukan biaya yang cukup besar. Agar pemerintah daerah dapat mengurus rumah tangganya sendiri dengan sebaikbaiknya maka diperlukan sumber-sumber pembiayaan yang cukup. Agar pendanaan penyelenggaraan pemerintah dapat terlaksana secara efisien dan efektif, maka diperlukan pendanaan penyelenggaraan pemerintah yang kewenagannya diatur oleh pemerintah daerah yang di biayai oleh APBD (Anggaran Pendapatan dan Belanja Daerah). APBD juga merupakan rencana kerja pemerintah daerah yang diwujudkan dalam bentuk uang dalam periode tertentu (satu tahun). Anggaran ini diperlukan sebagai alat untuk menetukan besarnya pengeluaran, membantu pengambilan keputusan dan perencanaan pembangunan, otorisasi pengeluaran di masa-masa yang akan datang, sumber pengembangan ukuran-ukuran standar untuk evaluasi kerja dan sebagai alat untuk memotivasi pegawai dan alat koordinasi bagi semua aktivitas dari berbagai unit kerja (Pekei, 2016).
Dengan adanya otonomi daerah berbagai daerah berlomba-lomba untuk terjadinya daerah yang mandiri, begitu juga dengan pemerintah Kota Manado dengan berbagai inovasi berusaha untuk tidak terlalu bergantung pada pemerintah pusat. Dilihat dari pertumbuhan PAD yang semakin meningkat dan semakin besarnya kontribusi PAD terhadap belanja daerah. Pemerintah di tuntut untuk lebih kreatif lagi dalam meningkatkan PAD-nya demi peningkatan akuntabilitas dan keleluasaan pembelanjaan APBD pemerintah Kota Manado.

\section{Rumusan Masalah}

Berdasarkan latar belakang tersebut maka yang menjadi permasalahan dalam penelitian ini, yaitu seberapa besar pertumbuhan PAD setiap tahunnya dalam mencukupi anggaran belanjanya setiap tahun, dan seberapa besar kontribusi pertumbuhan PAD terhadap Belanja Daerah yang ada di Kota Manado.

\section{Tujuan Penelitian}

1. Ingin mengetahui seberapa besar pertumbuhan PAD di Kota Manado.

2. Ingin mengetahui besarnya Kontribusi PAD terhadap Belanja Daerah di Kota Manado.

\section{Manfaat Penelitian}

1. Memberikan gambaran tentang pertumbuhan dan kontribusi PAD bagi akademisi yang akan mengembangkan penelitian ini selanjutnya.

2. Sebagai bahan masukan untuk pemerintah Kota Manado dalam pembuatan laporan program dan rancangan anggaran setiap tahun.

\section{METODE PENELITIAN}

\section{Waktu dan Tempat Pelaksanaan}

Penelitian ini di lakukan selama 4 bulan dari bulan September sampai dengan bulan November 2017 yang di mulai dari persiapan sampai dengan penyusunan laporan penelitian, dengan tempat penelitian adalah Instansi-instansi Pemerintah seperti Badan Pusat Statistika (BPS) Provinsi Sulawesi Utara Badan Pengelolaan Pajak dan Retribusi Daerah.

\section{Jenis dan Sumber Data}

Adapun jenis data yang di gunakan adalah data sekunder. Data ini di peroleh secara langsung dari Badan Pusat Statistika (BPS), Badan pengelolaan pajak dan retribusi daerah dan Badan Pengelolaan Keuangan dan Aset daerah. 


\section{Konsep Pengukuran Variabel}

Penelitian ini bertujuan ntuk mengetahui apakah terdapat perbedaan besaran pertumbuhan PAD dan seberapa besar kontribusi PAD terhadap Belanja Daerah di Kota Manado tahun 2011- 2016.

1. Pertumbuhan Pendapatan Asli Daerah (Dinata, 2013) merupakan suatu proses kenaikan output yang dapat di hitung dengan parameter yaitu:

$$
p=\frac{P A D i-P A D i^{-1}}{P A D i} \times 100
$$

Keterangan:

$$
\begin{aligned}
\mathrm{P} \quad= & \text { Pertumbuhan } \\
\text { PAD } i= & \text { Pendapatan Asli Daerah tahun } \\
& \text { sekarang } \\
\text { PAD } i-1= & \text { Pendapatan Asli Daerah tahun } \\
& \text { sebelumnya }
\end{aligned}
$$

2. Perhitungan Kontribusi PAD terhadap Belanja daerah.

$$
K=\frac{P A D}{\text { Total Belanja }} \times 100
$$

Keterangan

$\mathrm{K}=$ Kontribusi

PAD = Pendapatan Asli Daerah

Total Belanja $=$ Total Belanja Daerah

Tabel 1. Kriteria Kemampuan Keuangan Daerah

\begin{tabular}{lc}
\hline \multicolumn{1}{c}{ Distribusi PAD } & Kriteria \\
Terhadap Belanja Daerah $(\%)$ & Keuangan Daerah \\
\hline $0,00-10,00$ & Sangat Kurang \\
$10,01-20,00$ & Kurang \\
$20,01-30,00$ & Sedang \\
$30,01-40,01$ & Cukup \\
$40,01-50,00$ & Baik \\
$>50,01$ & Sangat Baik \\
\hline
\end{tabular}

Sumber: (Debora, 2014)

\section{HASIL DAN PEMBAHASAN}

\section{Gambaran Kota Manado}

Kota Manado merupakan Ibu Kota di Provinsi Sulawesi Utara sehingga menjadikan Kota Manado pusat dari pemerintahan Provinsi Sulawesi Utara. Secara geografis Manado terletak di anatara $1^{\circ}$

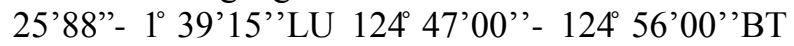
dan secara administratif berbatasan dengan sebelah utara Kabupaten Minahasa Utara, sebelah selatan berbatasan dengan Kabupaten Minahasa, sebelah timur berbatasan dengan Kabupaten Minahasa dan Kabupaten Minahasa Utara dan sebelah barat berbatasan dengan Laut Sulawesi. Kota Manado didiami oleh beberapa etnis besar dari Sulawesi Utara diantaranya Minahasa, Bolaang Mongondow dan Sangihe-Talaud dan juga berbagai golongan agama dengan mayoritas penduduk beragama Kristen. Meskipun Kota Manado didiami oleh berbagai etnis dan berbagai golongan agama namun masyarakat Kota Manado selalu hidup rukun dan damai, slogan "Torang Samua Basudara" seolah semakin memperkuat kerukunan hidup masyarakat Kota Manado.

Kota Manado sebagai ibu kota provinsi juga mempunyai 11 kecamatan. Malalaang, Sario, Wanea, Wenang, Tikala, Paal dua, Mapanget, Singkil, Tuminting, Bunaken, Bunaken Kepulauan. Luas wilayah Kota Manado tercatat 157,26 km² yang terbagi atas 11 kecamatan. Jumlah penduduk laki-laki 214.734 jiwa dan jumlah penduduk perempuan 213.172 jiwa dengan total penduduk 427.906 jiwa, Dimana jumlah penduduk terbanyak berada di Kecamatan Malalayang dengan jumlah 57.319 jiwa yang kemudian diikuti oleh jumlah penduduk dari Kecamatan Wanea dengan jumlah 56.509 jiwa, sedangkan jumlah penduduk terendah berada di Kecamatan Bunaken kepulauan yaitu dengan jumlah penduduk 6.167 jiwa (Manado.go.id)

\section{Visi dan Misi Kantor Wali Kota Manado}

\section{Visi}

1. Mewujudkan pemerintahan pelayanan yang baik, bersih serta demokratis yang berorientasi kepariwisataan.

2. Mewujudkan masyarakat Kota Manado yang berdaya saing mendukung kepariwisataan.

3. Mewujudkan lingkungan asri dan lestari yang menopang kepariwisataan.

\section{Misi}

1. Membangun Manado Kota "Cendekia" dengan sumber daya manusia yang cerdas dan tangguh melalui penigkatan kualitas pendidikan dan minat baca masyarakat, meningkatkan akses masyarakat terhadap layanan pendidikan untuk menunjang upaya peningkatan indeks pembangunan manusia.

2. Membangun Manado sebagai destinasi "Ekowisata" berbasis konservasi lingkungan laut dan kepualauan. Menciptakan identitas dan citra Kota sebagai pintu gerbang tujuan wisata dunia, khususnya pulau bunaken, silade, Manado Tua, dan Gunung Tumpa mewujdakan kawasan pantai dan sungai di Kota Manado sebagai kawasan Water Front City.

3. Membangun Masyarakat Kota yang "Religius" dan menjunjung tinggi nilai moral, sosial dan toleransi meningktakan kehidupan beriman masyarakat Kota Manado sesuia dengan Agama dan kepercayaan masing-masing. 
4. Membangun Kota yang memiliki "Daya Saing" dengan berorientasi pada peningkatan daya tarik investasi serta kualitas sumber daya Manusia dan kualitas layanan bidang pelayanan publik dan perizinan berbasis layanan teknologi informasi dan komunikasi.

5. Mewujudkan Kota Manado yang "Aman dan Nyaman. Melalui peningkatan kualitas sistem keamanan dan pemabngunan inrasturkur yang berkualitas dan ramah lingkungan, serta tertib ruang, menciptakan lingkungan perkotaan yang aman melalui peningkatan kualitas dan kuantitas pengawsan keamanan lingkungan serta pembangunan infrastruktur keamanan cerdas (Smart Security), membangun inrastruktur perkotaan yang berstandart tinggi dan mampu memberikan pelayanan yang optimal sesuai fungsi bagi masyarakat menciptakan kualitas lingkungan perkotaan yang lebih nyaman, bebas kumuh dan bertahan menghadapi resiko bencana dan dampak perubahan iklim.

6. Menciptakan Manado Kota yang sehat lewat peningkatan pelayanan kesehatan untuk menciptakan kondisi masyarakat yang lebih "Sehat Sejahtera" dengan lingkungan Kota yang bersih dan asri. Meningkatkan akses masyarakat terhadap layanan kesehatan dalam rangka meningkatkan derajat kesehatan masyarakat. Menciptakan lingkungan perkotaan lebih sehat melalui peningkatan kualitas pelayanan kebersihan kota dan peran masyarakat yang sadar bersih dalam pengelolaan sampah demi kualitas hidup dan kesehjatraan masyarakat.

\section{Perkembangan PAD Pemerintah Kota Manado}

Dalam era otonomi daerah sekarang ini, daerah yang diberikan kewenangan yang lebih besar untuk mengatur dan mengurus rumah tangganya sendiri tujuannya antara lain untuk lebih mendekatkan pelayanan pemerintah kepada masyarakat untuk memantau penggunaan dana oleh pemerintah dan meingkatkan persaingan antar daerah.

Sejalan dengan kewenangan tersebut pemerintah daerah lebih mampu menggali sumbersumber keuangan terlebih khusus untuk memenuhi kebutuhan daerah dalam pembangunan dan pembiayaan pemerintah yang berasal dari PAD.

Adapun jenis-jenis PAD yang di terima oleh Dinas Pendapatan pemerintah Kota Manado adalah pendapatan pajak, pendapatan retribusi daerah, pendapatan hasil perusahaan milik daerah dan pengelolaan kekayaan daerah yang di pisahkan, dan lain-lain pendapatan daerah yang sah.
Berikut Perkembangan sumber-sumber Pendapatan Asli Daerah Kota Manado Tahun 20112016.

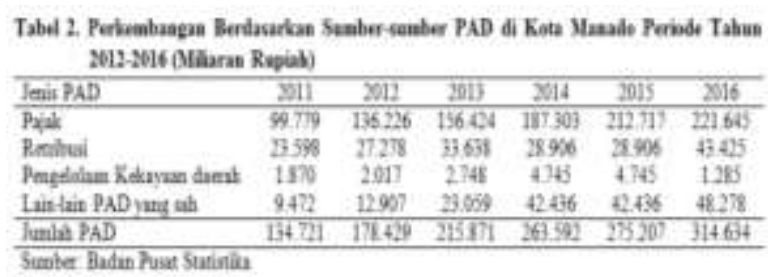

Berdasarkan Tabel 2, dapat diketahui peningkatan PAD Kota Manado terjadi setiap tahun. Dari segi jumlah PAD pada tahun 2011 sebesar Rp. 134.721, Pada tahun 2012 meningkat menjadi Rp. 178.429, pada tahun 2013 meningkat kembali sebesar Rp. 215.871. juga pada tahun 2014 mengalami peningkatan sebesar Rp.263.592, pada tahun 2015 mengalami peningkatan sebesar Rp.275.207, dan pada tahun 2016 peningkatan Jumlah PAD naik hingga sebesar Rp. 314.634.

Perkembangan PAD dari segi Pajak daerah meningkat setiap tahunnya hal ini dapat dilihat 2011 Pajak daerah berhasil diperoleh sebesar Rp. 99.779, pada tahun 2012 mengalami peningkatan menjadi Rp. 136.226, pada tahun 2013 masih dalam peningkatan sebesar Rp. 156.424, tahun 2014 juga masih dalam peningkatan sebesar Rp. 187.303, tahun 2015 mengalami peningkatan sebesar Rp. 212.717, hingga tahun 2016 Pajak daerah masih meningkat sebesar Rp. 221.645.

Perkembangan PAD dari segi Retribusi daerah mengalami fluktuasi naik turun dari tahun 2011 sebesar Rp. 23.598, sampai tahun 2012 meningkat sebesar Rp. 27.278, lalu meningkat kembali di tahun 2013 sebesar Rp. 33.638, pada tahun 2014 mengalami penurunan sehingga sampai Rp. 28.906, lalu pada tahun 2015 Retribusi daerah masih sama pada tahun sebelumnya sebesar Rp. 28.906, barulah pada tahun 2016 kembali mengalami kenaikan sebesar Rp. 43.425 .

Perkembangan PAD dari segi Pendapatan Hasil Pengelolaan Kekayaan Daerah yang dipisahkan pada tahun 2011 sebesar Rp. 1.870, kemudian pada tahun 2012 mengalami peningkatan sebesar Rp. 2.017, lalu pada tahun 2013 kembali mengalami peningkatan sebesar Rp. 2.748. Pada tahun 2014 kembali meningkat sebesar Rp. 4.745, kemudian pada tahun 2015 tidak mengalami perubahan tetap sebesar Rp. 4.745, dan pada tahun 2016 mengalami penurunan hingga menjadi Rp. 1.285.

Perkembangan PAD dari segi Lain-lain Pendapatan Daerah yang Sah pada tahun 2011 sebesar Rp. 9.472, kemudian pada tahun 2012 meningkat kembali sebesar Rp. 12.907, lalu pada tahun 2013 kembali meningkat sebesar Rp. 23.059, kemudia pada tahun 2014 meningkat 
sebesar Rp. 42.436, kemudian pada tahun 2015 sama sekali tidak mengalami peningkatan atau penurunan dengan pendapatan sebesar $\mathrm{Rp}$. 42.436, dan pada tahun 2016 kembali mengalami peningkatan dengan pendapatan sebesar Rp. 48.278.

Graik 1. Perkembangan Sumber-sumber PAD tahun 2011-2016 (Miliaran Rupiah)

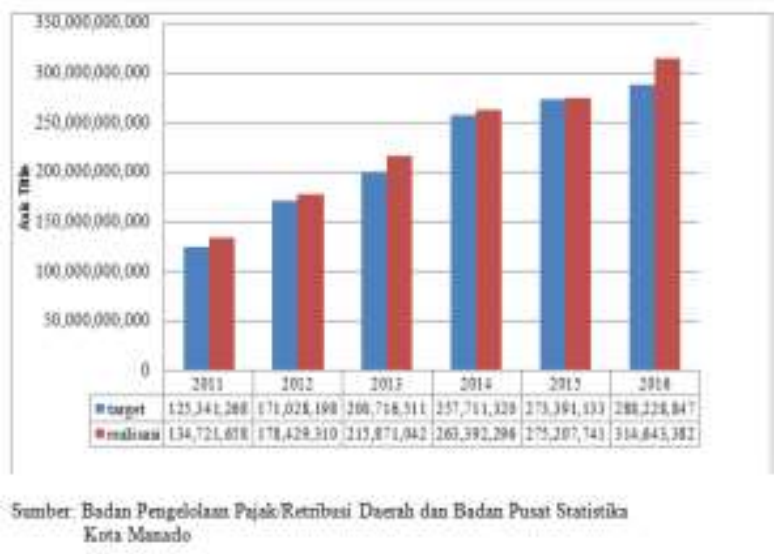

Berdasarkan Grafik 1 menunjukkan bahwa kinerja Pemerintah Daerah dalam hal menggali sumber-sumber PAD Kota Manado. Dari grafik 1 kita bisa melihat perkembangan pendaptan PAD berdasarkan target Pemerintah setiap tahunnya selalau naik terus dengan diikuti realisasi pendapatan dari jumlah PAD yang selalu melewati dari target yang telah ditetapkan. Pada tahun 2011 bisa kita lihat target pemerintah itu sebesar Rp. 125.341.268.702 dengan pencapaian pendapatan PAD di tahun 2011 realisasinya sebesar Rp. 134.721.658.450 ini artinya ada bertambah sebesar Rp. 9.380.389.748 yang mampu didapatkan oleh Pemerintah Kota Manado, begitu juga pada tahun 2012 target awal yang telah ditetapkan untuk penerimaan dari hasil PAD sebesar Rp. 171.028.198.834 dengan pencapaian pendapatan PAD realisasinya sebesar Rp. 178.429.310.832 ini artinya ada bertambah sebesar Rp. 7.401.111.998 diluar dari target yang telah ditetapkan, begitu juga tahun 2013 target untuk pendapatan PAD sebesar Rp. 200.716.511.942 dengan realisasinya sebesar Rp. 215.871.042.643 ini artinya ada bertambah sebesar Rp. 15.154.530.701 diluar target yang telah ditetapkan, pada tahun 2014 target untuk pendapatan PAD yang telah ditetapkan oleh pemerintah sebesar Rp. 257.711.320.560 dengan realisasinya sebesar Rp. 263.392.296.958 ini artinya ada beratambah sebesar Rp. 5.681.162.958 diluar target yang telah ditetapkan, tahun 2015 target pendapatan PAD sebesar Rp. 273.391.133.000 dengan realisasinya sebesar Rp. 275.207.741.463 ini artinya ada bertambah sebesar Rp. 1.816.608.463 dari target yang telah ditetapkan, dan pada tahun 2016 target yang telah ditetapkan sebesar Rp. 288.228.847.854 dengan realisasinya sebesar Rp. 314.643.382.648 ini artinya ada bertambah sebesar Rp. 26.414.534.794 dari target yang telah ditetapkan.

PAD merupakan Sumber-sumber pendapatan yang memang selalu harus dipacu pertumbuhannya, di era otonom ini Pemerintah Kota Manado sangat dituntut demi pembiayaan pembangunan dan peningkatan pertumbuhan ekonomi masyarakat. Pemerintah Kota Manado sudah bisa dibilang maksimal dikarenakan setiap tahunnya pertumbuhan PAD Kota Manado sudah berada apa yang diharapkan, karena setiap tahunnya pendapatan PAD Kota Manado sudah memenuhi target dari apa yang ditetapkan Pemerintah Kota Manado bahkan disertai dengan pertumbuhan PAD setiap tahunnya.

Tabel 3. Kontribusi Pajak dan Perkembangan Terhadap PAD (Miliaran Rupiah)

\begin{tabular}{lccc}
\hline Tahun & Pajak (Rp) & Jumlah PAD (Rp) & Kontribusi (\%) \\
\hline 2011 & 99.779 & 134.721 & 74,06 \\
2012 & 136.226 & 178.429 & 76,34 \\
2013 & 156.424 & 215.871 & 72,46 \\
2014 & 187.303 & 263.592 & 71,05 \\
2015 & 212.717 & 275.207 & 77,29 \\
2016 & 221.645 & 314.634 & 70,44 \\
\hline
\end{tabular}

Berdasarkan Tabel 3 pendapatan dari sektor pajak merupakan sumber terbesar dalam PAD, menurut dari tabel 3 jumlah penerimaan PAD dari sektor pajak memiliki kontribusi rata-rata sebesar 70\% dari tahun 2011-2016. Hasil ini dilihat dari pertumbuhan pendapatan lewat pajak yang selalu naik tahun ke tahun, pada tahun 2011-2016 bertumbuhn sebesar 26,75\%, tahun 2012-2013 bertumbuh sebesar 12,91\%, tahun 2013-2014 bertumbuh sebesar 16,48\%, tahun 2014-2015 bertumbuh sebesar 11,94\%, tahun 2015-2016 bertumbuh sebesar 4,19\%. Pemasukan terbesar untuk sektor pajak yaitu pajak hotel dan pajak restoran.

Tabel 4. Kontribusi dan Perkembangan Retribusi Terhadap PAD (Miliaran Rupiah)

\begin{tabular}{cccc}
\hline Tahun & $\begin{array}{c}\text { Retribusi } \\
(\mathrm{Rp})\end{array}$ & $\begin{array}{c}\text { Jumlah PAD } \\
(\mathrm{Rp})\end{array}$ & $\begin{array}{c}\text { Kontribusi } \\
(\%)\end{array}$ \\
\hline 2011 & 23.598 & 134.721 & 17,51 \\
2012 & 27.278 & 178.429 & 15,28 \\
2013 & 33.638 & 215.871 & 15,58 \\
2014 & 28.906 & 263.592 & 10,96 \\
2015 & 28.906 & 275.207 & 10,50 \\
2016 & 43.425 & 314.634 & 13,80 \\
\hline
\end{tabular}

Berdasarkan Tabel 4 pendapatan dari retribusi masih juga masuk dalam sektor yang memiliki pendapatan terbesar dengan kontribusi sebesar di atas 10\% dari tahun 2011-2016. Hasil ini 
dilihat dari pertumbuhan pendapatan lewat retribusi dari tahun 2011-2012 sebesar 13,49\%, tahun 20122013 sebesar 18,90\%, tahun 2013-2014-16,37\%, tahun 2014-2015 tidak mengalami pertumbuhan $0 \%$ kaerena hampir semua sektor mengalami naik dan turun bersamaan dengan tahun sebelumnya, tahun 2015-2016 naik lagi sebesar 33,43\%. Dengan sumber terbesar sebagai penyumbang untuk pendapatan retribusi yaitu retribusi khusus parkir dan percobaan kendaraan bermotor.

\begin{tabular}{cccc}
$\begin{array}{c}\text { Tabel 5. Kontribusi dan Perkembangan Pengelolaan Kekayaan } \\
\text { Daerah (Miliaran Rupiah) }\end{array}$ \\
\hline Tahun & $\begin{array}{c}\text { Pengelolaan } \\
\text { Kekayaan } \\
\text { Daerah (Rp) }\end{array}$ & $\begin{array}{c}\text { Jumlah PAD } \\
(\mathrm{Rp})\end{array}$ & $\begin{array}{c}\text { Kontribusi } \\
(\%)\end{array}$ \\
\hline 2011 & 1.870 & 134.721 & \\
2012 & 2.017 & 178.429 & 1,38 \\
2013 & 2.748 & 215.871 & 1,13 \\
2014 & 4.745 & 263.592 & 1,27 \\
2015 & 4.745 & 275.207 & 1,8 \\
2016 & 1.285 & 314.634 & 0.40 \\
\hline
\end{tabular}

Berdasrarkan Tabel 5 kontribusi dari pengelolaan kekayaan daerah untuk PAD tidak terlalu berarti karena kecilnya kontribusi yang diberikan dengan rata-ratanya hanya 1\%. Dari tahun 2011-2012 pertumbuhannya hanya sebesar $7,28 \%$, tahun $2012-$ 2013 pertumbuhannya 26\%, tahun 2013-2014 pertumbuhannya 42,08\%, tahun 2014-2015 pertumbuhannya sebesar $0 \%$ karena sumber-sumber pendapatanya masih sama yang diperoleh Pemerintah pada tahun sebelumnya, tahun 2015-2016 menurun sehingga pertumbuhannya $-26,96 \%$. Ini menjadi koreksi untuk Pemerintah Kota Manado bahwa harus mencoba menggait investor dari luar dan meningkatkan seluruh unit usaha milik daerah untuk peningkatan pendapatan Pengelolaan kekayaan daerah.

Tabel 6. Kontribusi dan Perkembangan Lain-lain PAD

\begin{tabular}{cccc} 
yang Sah & & \\
\hline Tahun & $\begin{array}{c}\text { Lain-lain PAD } \\
\text { Yang Sah (Rp) }\end{array}$ & $\begin{array}{c}\text { Jumlah PAD } \\
(\mathrm{Rp})\end{array}$ & $\begin{array}{c}\text { Kontribusi } \\
(\%)\end{array}$ \\
\hline 2011 & 9.472 & 134.721 & 7,03 \\
2012 & 12.907 & 178.429 & 7,23 \\
2013 & 23.059 & 215.871 & 10,68 \\
2014 & 42.436 & 263.592 & 16,09 \\
2015 & 42.436 & 275.207 & 15,41 \\
2016 & 48.278 & 314.634 & 15,34 \\
\hline
\end{tabular}

Berdasarkan Tabel 6 kontribusi perkembangan pendaptan PAD yang sah, pendapatan ini merupakan dana bagi hasil dan pendapatan dari provinsi. Yang dari tahun ke tahun cukup memberikan kontribusi untuk peningkatan PAD. Tahun 2011-2012 pertumbuhannya sebesar $26,61 \%$, tahun 2012-2013 bertumbuh sebesar $44,02 \%$, tahun 2013-2014 bertumbuh sebesar $45,66 \%$, tahun 2014-2015 tidak mengalami pertumbuhan karena dari data yang didapat setiap sektornya mengalami kenaikan dan penurunan yang sama persis dan pada tahun 2015-2016 pendaptan PAD yang sah mengalami pertumbuhan sebesar $12,10 \%$. Dengan sumber pendapatan terbesar yaitu dana bagi hasil dengan Pemerintah Provinsi dan dana bantuan dari Provinsi.

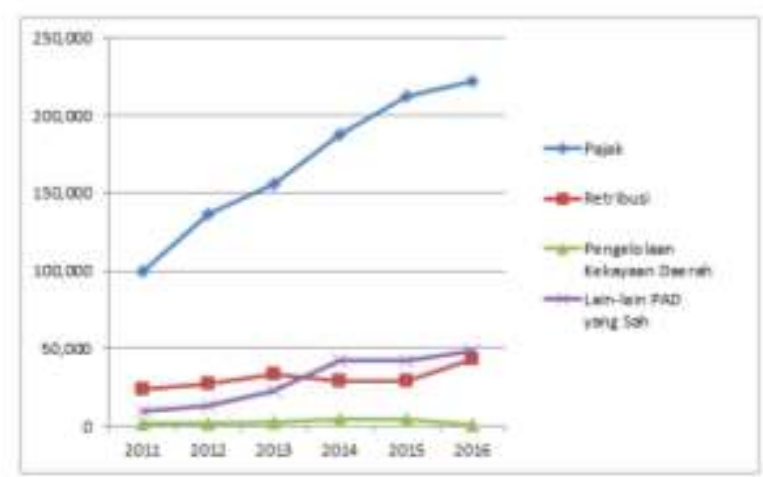

Grafik 2. Laju Pertumbuhan Setiap Sektor Didalam PAD Tahun 2011-2016 (Miliaran Rupiah)

Berdasarkan Grafik 3 yaitu laju pertumbuhan setiap sektor yang ada dalam PAD sektor pajaklah yang menjadi penyumbang terbesar dalam hal pendapatan untuk PAD di sertai dengan pertumbuhan yang besar sehingga PAD Kota Manado Banyak menerima pemasukan dari sektor pajak, di ikuti dengan pendapatan retribusi dan lainlain PAD yang sah, cenderung kedua sektor ini saling bergantiang dalam mengalami kenaikan dan penurunannya dalam segi pertumbuhan tetapi keduanya tidak mampu melebihi pendapatan diatas Rp. 50.000.000.000, dan sektor yang paling rendah dalam memberikan kontribusinya dan rendahnya pendapatan membuat sektor pengelolaan kekayaan daerah Kota Manado tidak mampu mengimbangi laju pertumbuhan dalam segi pendapatan, ini menjadi pekerjaan rumah untuk Pemerintah Kota Manado dalam hal melaksanakan pungutan terhadap setiap unit usaha yang ada didalam PAD untuk mencari cara dalam hal peningkatan sektor-sektor yang kurang memberikan kontribusi terhadap PAD.

\section{Pertumbuhan PAD}

Tabel 7 menunjukkan bahwa tingkat pendapatan asli daerah di Kota Manado mengalami penigkatan selama enam tahun terakhir, dilihat pada tahun 2011 pendapatan asli daerah sebesar 134.721.723 dan terus menigkat hingga tahun 2016 yaitu sebesar 314.634.922 hal ini berarti pemerintah Kota Manado mampu mengelola dan merealisasikan potensi ekonomi yang ada menjadi bentuk-bentuk kegiatan ekonomi yang menjadi sumber pemerintah 
daerah yang nantinya membiayai pembangunan yang ada di Kota Manado.

Tabel 7. Pertumbuhan Pendapatan Asli Daerah Kota Manado Tahun 2011-2016 (Miliaran Rupiah)

\begin{tabular}{ccc}
\hline Tahun & PAD $(\mathrm{Rp})$ & Pertumbuhan PAD $(\%)$ \\
\hline 2011 & 134.721 .723 & - \\
2012 & 178.429 .311 & 24,49 \\
2013 & 215.871 .043 & 17,34 \\
2014 & 263.592 .317 & 18,10 \\
2015 & 275.207 .649 & 4,22 \\
2016 & 314.634 .922 & 12,53 \\
\hline
\end{tabular}

Rata-rata $15,33 \%$

Pertembuhan tertinggi (2012) 24,49\%

Pertumbuhan Terendah (2015) $\quad 4,22 \%$

Sumber Data Hasil Olahan

Pertumbuhan PAD terjadi setiap tahunyang ada di Kota Manado, mengindikasikan bahwa kemampuan pemerintah Kota Manado mampu menyerap Sumber-sumber dana yang ada disetiap sektor sehingga pertumbuhan PAD di Kota Manado selalu Meningkat, dilihat dari tahun 2012 pertumbuhan PAD sebesar 24,49\%, pada tahun 2013 peningkatan PAD dalam Pertumbuhan yang sedikit menurun pada angka 17,24\%, hingga tahun 2014 penigkatan pertumbuhan PAD masih dalam jalur yang baik dengan ada penigkatan pertumbuhan di angka $18,10 \%$, barulah pada tahun 2015 pertumbuhan PAD jauh menurun di angka 4,22\% faktor ini disebabkan oleh tiga dari 4 sektor PAD tidak mengalami penigkatan yaitu Pendapatan retribusi, pendapatan pengelolaan kekayaan daerah dan pendapatan lain-lain yang sah dan pada tahun 2016 pertumbuhan PAD mengalami penigkatan sebesar $12,53 \%$ lewat peningkatan setiap sektor.

Dengan peningkatan setiap sumber PAD dari tahun ke tahun kiranya pemerintah Kota Manado lebih berkerja keras lagi dalam mengembangkan setiap sektor-sektor yang mampu memberikan pendapatan yang lebih besar, sehingga pemerintah Kota Manado lebih mandiri dalam proses pembangunan daerah dari berbagai aspek sehingga mengurangi ketergantungan kepada pemerintah pusat.

\section{Kontribusi PAD Terhadap Belanja Daerah di Kota Manado}

\begin{tabular}{|c|c|c|c|c|}
\hline Taban & $\begin{array}{l}P A D \\
(\mathrm{Rp})\end{array}$ & $\begin{array}{l}\text { Belanju } \\
(\mathrm{Rp})\end{array}$ & $\begin{array}{c}\text { Koetribua } \\
\text { (5) }\end{array}$ & Kriteria \\
\hline 2011 & 134.721723 & $897.06+922$ & 15,01 & Karang \\
\hline 2012 & 178.49311 & 1054.435 .233 & 1692 & Kanug \\
\hline 2013 & 215.831 .043 & 1.317 .428509 & 16,38 & Karang \\
\hline 2014 & 263592317 & 1381124804 & 19,88 & Karang \\
\hline 2015 & 275207649 & 1.507594709 & 15,25 & Karang \\
\hline 2016 & 314634922 & 2109551251 & 1491 & Karng \\
\hline
\end{tabular}

\begin{tabular}{ll}
\hline Rata-rata & $16,75 \%$ \\
Kontribusi Tertinggi (2014) & $19,08 \%$ \\
Kontribusi Terendah (2016) & $14,91 \%$ \\
\hline Sumber Data Hasil Olahan &
\end{tabular}

Berdasarkan skala kriteria kemampuan keuangan daerah, untuk pemerintah Kota Manado pada tahun 2011, PAD Kota Manado memberikan kontribusi sebesar 15,01\% dari Belanja daerah dengan kriteria kurang, sementara itu untuk tahun 2012 mengalami kenaikan kontribusi sebesar menjadi $16,92 \%$ dengan kriteria kurang, padahal pada tahun 2012 memiliki pertumbuhan PAD tebesar dengan mencapai $24 \%$, hal ini di sebabkan karena peningkatan belanja daerah mengalami pertumbuhan 10\% lebih sehingga masih ada dalam kategori kurang, pada tahun 2013 kontribusi PAD terhadap belanja daerah masih terhenti di angka $16,38 \%$ bahkan cenderung menurun dari tahun sebelumnya sehingga masih dalam kriteria kurang, pada tahun 2014 kontribusi PAD mengalami kenaikan sampai angka $19,08 \%$ persen tetapi belum mampu meningkatkan dalam hal kriteria yang kurang, begitu juga pada tahun 2015 kontribusi PAD bahkan menurun di angka $18,25 \%$ di karenakan peningkatan belanja daerah masih melonjak naik sama seperti tahun sebelumnya sehingga untuk kriterianya masih kurang, dan pada tahun 2016 peningkatan PAD menurun di angka $14,91 \%$ di karenakan peningkatan pertumbuhan belanja daerah melonjak sebesar $30 \%$ dan masih dalam kriteria yang kurang untuk kontribusi PAD terhadap belanja daerah, ini di karenakan beban belanja yang sangat besar dan pemerintah Kota Manado sedang melakukan pembanguanan besar-besaran sehingga untuk menutup beban belanja yang besar pemerintah kota berharap sepenuhnya terhadap bantuan dari pemerintah pusat.

\section{Perbandingan Pertumbuhan PAD Dengan Kontribusi PAD}

Grafik 3. Perbandingan Pertumbuhan PAD dengan Kontribusi PAD (\%)

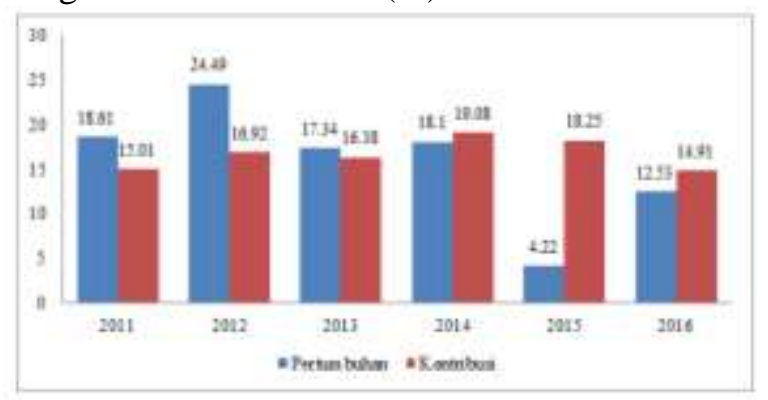

Lewat hasil yang ada didalam Grafik 3, bisa dilihat perbandingan antara pertumbuhan PAD dengan kontribusi PAD cenderung naik turun bisa dilihat di 3 tahun pertama yaitu tahun 2011-2013, pertumbuhan PAD mengungguli dari kontribusi PAD. Karena keempat sektor yaitu pajak, retribusi, pengelolaan kekayaan daerah yang sah dan lain-lain pad yang sah mengalami pertumbuhan yang signifikan. Lain hal dengan kontribusi masih dalam kriteria yang kurang karena di tekan oleh beban biaya Belanja Daerah. 
Peningkatan Belanja Daerah yang sangat besar dan pemerintah daerah yang belum mampu memaksimalkan PAD untuk bisa sekirannya membiayai setengah dari jumlah Belanja Daerah, sehingga dari tahun ketahun PAD selalu mengalami pertumbuhan tetapi dalam hal untuk memberi kontribusinya untuk Belanja Daerah masih dalam kriteria yang kurang walaupun di tahun 2014-2016 kontribusi PAD mengungguli dari jumlah Pertumbuhan PAD Kota Manado.

\section{KESIMPULAN DAN SARAN}

Kesimpulan

Berdasarkan hasil uraian dapat diambil kesimpulan sebagai berikut:

1. Untuk kontribusi PAD dalam memenuhi Belanja daerah Kota Manado tahun 20112016 berada didalam kriteria kurang.

2. Peningkatan Pertumbuhan PAD Kota Manado dari tahun 2011-2016 cenderung flukuaktif, dengan dari sektor pajak memiliki kontribusi tertinggi untuk pendapatan PAD, diikuti sektor retribusi, lain-lain PAD yang sah, dan terakhir pengelolaan kekayaan daerah.

\section{Saran}

1. Disarankan untuk penelitian selanjutnya untuk dapat menganalisis tidak hanya pada perubahan kontribusi PAD terhdap Belanja daerah. Seperti contoh dapat menambahkan variabel pertumbuhan ekonomi dan atau pengaruhnya dengan kinerja pemerintah daerah sehingga hasil dan informasi dari dampak diberlakukan otonomi daerah lebih luas dan menambah periode pengamatan agar hasilnya dapat menunjukkan keadaan terkini.

2. Mempertahankan kinerja pengelolaan yang sudah tertata dengan baik di pemerintahan Kota Manado terlebih dalam pengelolaan sumber-sumber Pendapatan Asli Daerah yang masih belum terkelola secara maksimal agar dapat memberikan kontribusi yang lebih maksimal terhadap Belanja Daerah.

3. Membuka sektor-sektor ekonomi potensial yang dapat menjadi sumber-sumber pendapatan daerah agar dapat meningkatkan taraf kemandiriannya dan tidak terlalau bergantung pada kucuran dana dari Pemerintah Pusat.

\section{DAFTAR PUSTAKA}

Anonim. Tanpa tahun. Gambaran Umum Kota Manado-Pemerintah Kota Manado.www. Manado Kota.go.id

Firstianto, 2015. Analisis Pengaruh Pertumbuhan Ekonomi, Pendapatan Asli Daerah (PAD), Produk Domestik Regional Bruto (PDRB), dan Belanja Modal, Terhadap Fiskal Stress Pada Kabupaten dan Kota di Provinsi Jawa Tengah. Skripsi akultas Ekonomi dan Bisnis Universitas Diponegoro Semarang.

Halim. A, 2007, Akuntansi Keuangan Daerah, karya Salemba Empat Jakarta.

Nugroho. F, 2012. Pengaruh Belanja Modal Terhadap Pertumbuhan Keuangan Daerah Dengan Pendapatan Asli Daerah (PAD) Sebagai variabel Intervening di Provinsi jawa Tengah. Fakultas Ekonomi dan Bisnis Diponegoro Semarang.

Pekei. B, 2016. Konsep dan Analisis Efektifitas Pengelolaan Keuangan Daerah di Era Otonomi. Penerbit Taushia.

Soleha. I. D, 2012. Kontribusi Pendapatan Asli Daerah Terhadap Belanja Pembangunan Daerah Pemerintah Daerah Kota Bekasi. Jurusan Akuntansi Fakultas Ekonomi Universitas Gunadarma. 